\title{
STUDENT MENTAL HEALTH
}

$I^{\mathrm{F}}$ F one asks an examiner of the old-fashioned, bluff, extraverted type why students fail in their examinations he will possibly reply: "Because they are insufficiently prepared". No doubt he will be content to leave it at that, but if one continues the Socratic questioning and demands: "Why are they insufficiently prepared?" one will be told: "Because they haven't worked enough". But this is not the com. plete answer, even supposing that one is told that their lack of work depends on a poor personality, laziness, or something of the sort.

These students who pose such problems are, as Dr. Malleson pointed out at a conference on the mental health of students recently held in London*, those who have surmounted the difficult hurdles of the 'eleven plus', the Common Entrance, the General Certificate of Education examinations, and so on in the past. Why have they failed at the university?

The papers read at the conference suggest that there is no simple answer. Although the student may have been successful at school, there are psychological difficulties associated with university life which may interfere with his work. These range from home-sickness, if he lives in a hostel, or domestic unrest associated with parental quarrelling, if he lives at home to such grave psychological illnesses as schizophrenia, depression and the severe crippling neuroses.

Student failure may mean that a valuable young man gives up further education and takes up work inferior to his intellectual capacity. It means, moreover, a great deal of expense to the nation. It is estimated that a student costs about $£ 700$ a year to

* World University Service. Student Mental Health: Report of a Conference held at Campbell Hall, London, 8th-9th April, 1961 . Pp. 28. $6 d$. educate at a university. If he gives up his academic career, as most students that fail do, after a year and a half, he has wasted at least a thousand pounds of public money. When one considers the number of students the loss is potentially enormous.

What is to be done about it? The answer lies, to some extent, in the work of the psychiatric advisers, who have the opportunity of examining students complaining of psychological symptoms. Many universities have such a unit and, as Dr. Malleson emphasizes, if only four students a year are saved from giving up their academic careers in a year the adviser has earned his keep.

Such an advisory unit is not primarily to treat nervous or mental illness, although one of its functions is early diagnosis, but to help the much larger number of students to overcome the usual adolescent difficulties. Among those who complain of comparative trivialities the more sinister illnesses are found, and even these, if discovered early, can sometimes be helped.

The time has passed when students should be thrown ruthlessly into university life to sink or swim. Such a policy may have sounded bold and manly, but many young men with otherwise a fine intellectual future have sunk; have worried over a triviality until they have broken down or taken their lives uselessly.

Probably all those who are student advisers will agree that we do not know everything regarding the problems of academic life. It is one of the advantages of an advisory unit that there is an enormous amount of material for research purposes, and, since the student is a picked man, derived from an intellectual élite. Ultimately this work should throw a valuable light not only on student problems but also on mental health in general.

\section{TRAWL FISHING IN THE TROPICAL ATLANTIC}

\section{Catch-rates and Composition}

$I^{T}$

is notoriously difficult to assess relative productivity between trawl fisheries in different parts of the world because of the inherent differences in fishing power of the vessels operating each fishery. Though it may be possible ${ }^{1}$ to apply factors to convert the catch-rates of vessels of similar type, but of different size, to a standard form, this is generally only practicable within a limited geographical area. The investigations of the Colonial Office vessel, Cape St. Mary, off West Africe in 1952-57 and off South America in 1957-58, working with the same officers and gear on both sides of the Atlantic, offer an opportunity to compare the standing crop, in terms of catch-rate, of the demersal fish of the two areas. Mitchell and McConnell ${ }^{2}$ have described their investigations off Georgetown on the Guiana coast, and an account of the work off West Africa is now in preparation ${ }^{3}$. Salzen ${ }^{4}$ has described some early results from Ghana with the same vessel, though with a different crew.

The Cape St. Mary was a 100-ft. (between perpendiculars) steel trawler of rather typical North Sea design, of 238 gross tons and with 385-h.p. Diesel engine; details of her construction and gear are given in ref. 2 . The trawls, in both areas, were of the Peter Carey type, $72 \mathrm{ft}$. on the head-rope, and were normally worked with 25 -fathom bridles.

In the silty water and on the muddy deposits of those parts of the tropical Atlantic coast-line where there is heavy run-off of surface water from the land, there are few, if any, reef corals, and the ground is suitable for trawling; the demersal fish fauna is superficially similar on both coasts, comprising a large number of species, relative to temperate faunas, principally of Sciaenidae, Drepanidae, Pristi. pomatidae, Ariidae and Cynoglossidae, off West Africa, and of Scianidae, Pomadasydae, Gerridae and Ariidae off British Guiana. On harder, sandy deposits the fauna comprises principally Sparidae, Lethrinidae and Lutjanidae off West Africa, and Serranidae and Lutjanidae off British Guiana. However, the percentage composition of the catch is rather different off West Africa and off that part of South America (Table 1) which was investigated.

There appears to be a much greater dominance of Scianidae in the British Guiana catches than in those 